\title{
PENGEMBANGAN PERMAINAN MAKE A MATCH BERBASIS KOMPUTER SEBAGAI MEDIA PENGAYAAN
}

\author{
Rendy Putra Pratama1, Rochmawati ${ }^{2}$ \\ 1,2 Pendidikan Akuntansi, Universitas Negeri Surabaya \\ e-mail: rendypratama16080304079@mhs.unesa.ac.id
}

\begin{abstract}
Learning media is believed to be one of the important parts of the learning process, especially computer-based media. This study aims to develop a computer game-based media Make a Match and to analyze its feasibility as a media enrichment. This study provided a type of educational Research and Development (R\&D) by referring to the model of development ADDIE (Analysis, Design, Development, Implementation, and Evaluation). The result of validations by material experts, linguists, and media experts showed that the average worthiness of assessment was $86,27 \%$. The average percentage revealed the number of $90,1 \%$ in the material aspect, $81,4 \%$ in the linguistics aspect, and $86,7 \%$ in the media aspect. Therefore, this computer based-game is very decent to be used as a media enrichment for students.
\end{abstract}

Keywords: a computer game-based media, make a match, enrichment media, merchandise inventory

Received: 26 Juli 2020

Accepted: 12 September 2020

Published: 26 Desember 2020

\section{PENDAHULUAN}

Terwujudnya pembelajaran yang berkualitas dapat dipengaruhi oleh banyak faktor, termasuk di dalamnya yaitu media yang digunakan dalam pembelajaran (Setyosari, 2014). Penggunaan media pembelajaran tidak hanya dapat memudahkan komunikasi antara guru dan peserta didik tetapi juga dapat meningkatkan motivasi belajar peserta didik (Sanjaya dalam Aghni, 2018). Peningkatan motivasi belajar siswa diharapkan dapat meningkatkan hasil belajar siswa tersebut.

Media pembelajaran sendiri terdiri dari banyak jenis dan klasifikasi dimana salah satunya media pembelajaran yang diklasifikasikan berdasarkan perkembangan teknologi (Munadhi dalam Aghni, 2018). Lebih lanjut Munadhi menyebutkan bahwa berdasarkan Seels \& Glasgow, terdapat dua klasifikasi media menurut perkembangan teknologi yaitu media tradisional dan media teknologi mutakhir. Salah satu contoh dari media teknologi mutakhir yaitu media komputer.

Saat ini, penggunaan teknologi di bidang pendidikan berkaitan erat dengan penggunaan komputer atau perangkat laptop. Teknologi pendidikan berbasis komputer mengharuskan penggunanya melakukan interaksi untuk mendapatkan informasi dan pengetahuan yang diinginkan serta sebagai bentuk berlangsungnya proses belajar (Darmawan, 2015). Komputer merupakan sarana prasana berbasis teknologi modern yang sering ditemui di sekolah. Salah satu upaya dalam pengembangan teknologi pendidikan di dalam sekolah yaitu dengan menggunakan 
media pembelajaran berbasis komputer, seperti media pengayaan berbasis komputer yang diharapkan dapat meningkatkan kualitas hasil belajar siswa di dalam pembelajaran.

Menurut Hamdani (2011), terdapat tiga tujuan pemakaian komputer dalam proses pembelajaran. Pertama, tujuan kognitif yaitu komputer mampu mengajarkan konsep aturan, prinsip, langkah-langkah, proses, dan perhitungan yang kompleks. Kedua, tujuan psikomotor yaitu komputer mampu menciptakan kondisi dunia kerja melalui bentuk pembelajaran permainan dan simulasi. Ketiga, tujuan afektif yaitu komputer mampu menggugah perasaan melalui program yang berisi potongan klip suara atau video. Akhir-akhir ini pemakaian komputer banyak ditujukan untuk tujuan psikomotor yaitu dalam bentuk media permainan (games).

Penelitian ini meneliti mata pelajaran akuntansi keuangan dengan materi persediaan. Dengan mempelajari materi ini diharapkan peserta didik mampu menguasai materi dan mampu menyelesaikan permasalahan yang berhubungan dengan aspek tranksaksi maupun kegiatan operasional yang ada di dalam materi persediaan. Materi persediaan diajarkan kepada peserta didik dan dilanjutkan program pengayaan bagi peserta didik yang telah mencapai Kriteria Ketuntasan Minimal (KKM). Penetapan nilai KKM yang tepat akan menghasilkan penilaian ketuntasan belajar yang berguna untuk memposisikan siswa. Tingkat penilaian belajar peserta didik mempunyai perbedaan dari program pembelajaran yang telah dilakukan. Dari hasil penilaian tersebut, guru dapat mengetahui nilai dari peserta didik lalu menentukan program remidial untuk peserta didik yang belum memenuhi KKM dan memberikan program pengayaan bagi peserta didik yang telah memenuhi KKM (Mulyasa, 2014).

Pengayaan merupakan tindakan yang diberikan kepada peserta didik apabila sudah mencapai ketentuan saat belajar agar dapat meningkatkan wawasan serta memperdalam pengetahuannya pada materi yang telah dipelajarinya. Mukhtar \& Rusmini (2005) menjelaskan bahwa kegiatan pengayaan adalah kegiatan yang relatif bebas, karena membantu siswa untuk memperdalam pemahaman dalam suatu pembelajaran apabila telah tuntas dalam KKM. Dalam melakukan pengayaan, guru memberikan tugas kepada siswa berupa kegiatan yang diantaranya menjadi tutor sebaya, mengembangkan kemampuan dengan mengerjakan latihan soal dari materi yang sedang dibahas, atau mengerjakan permainan yang harus dikerjakan oleh siswa. Menurut Dirman \& Juarsih (2014), kegiatan pengayaan memberikan kesempatan untuk siswa yang memiliki kemampuan lebih dalam berfikir sehingga siswa mampu mengembangkan minat, bakat, dan memaksimalkan kemampuannya. Dalam upaya pelaksanaan pengayaan pada proses pembelajaran, maka dilakukannya alternatif dengan menggunakan media pengayaan yang dapat membantu mempermudah kegiatan pengayaan dan agar suasana pembelajar tidak hanya dengan model direct learning oleh guru.

Berdasarkan hasil observasi di SMK Negeri 10 Surabaya, diperoleh informasi dari guru mata pelajaran akuntansi keuangan yaitu terdapat banyak siswa yang telah memahami dan mencapai KKM dalam materi persediaan. Hal ini terbukti dari 34 jumlah siswa dalam satu kelas XI AKL (Akuntansi dan Keuangan Lembaga) 1, hanya 8 siswa yang belum tuntas, sedangkan 26 siswa mampu mencapai syarat KKM yang telah ditetapkan. Berdasarkan data tersebut, kegiatan remidial ditujukan untuk peserta didik yang belum tuntas sedangkan untuk peserta didik 
yang telah tuntas akan diberikan program pengayaan. Informasi selanjutnya yang diperoleh bahwa media yang digunakan untuk kegiatan pengayaan yaitu media PowerPoint. Guru merasa dengan menggunakan media PowerPoint dapat membuat siswa mudah memahami materi dan menciptakan suasana menyenangkan dalam pembelajaran. Tetapi justru sebaliknya kondisi ini membuat siswa bosan dan kurangnya motivasi saat menyelesaikan soal pengayaan yang diberikan oleh guru. Oleh karena itu harus ada inovasi dalam media pengayaan supaya dapat meningkatkan minat belajar serta menciptakan suasana menyenangkan dalam program pengayaan.

Berdasarkan data di atas, peneliti ingin mengembangkan alternatif media pengayaan dalam bentuk permainan Make a Match berbasis komputer yang dapat digunakan secara mandiri maupun berkelompok oleh peserta didik. Alasan dipilihnya permainan Make a Match berbasis komputer sebagai media pengayaan agar dapat meningkatkan motivasi siswa, membuat kegiatan pengayaan menyenangkan, membangun pengalaman belajar, dan memberikan kesempatan kepada peserta didik untuk melakukan eksperimen di dalam ruang bermain yang aman dan untuk merefleksikan hasil keputusan yang mereka buat.

Make a Match atau mencari pasangan merupakan salah satu teknik dalam pembelajaran kooperatif dimana siswa mencari pasangan sekaligus belajar tentang suatu konsep atau topik dalam suasana yang menyenangkan (Lie, 2010). Suasana yang menyenangkan memungkinkan peserta didik menjadi lebih termotivasi dalam beajar. Penerapan model pembelajaran kooperatif dengan Make a Match ini terbukti dapat meningkatkan motivasi belajar siswa dalam pembelajaran akuntansi (Andriyani, 2015). Selain meningkatkan motivasi belajar, implementasi teknik pembelajaran Make a Match juga dapat meningkatkan hasil belajar atau prestasi belajar siswa terutama dalam ranah kognitif dalam pembelajaran akuntansi (Andriyani, 2015; Wulandari, 2012; Afanty, Siswandari, \& Jaryanto, 2016).

Jenis Make a Match yang sebelumnya diterapkan lebih banyak menggunakan bantuan media berbasis kartu, belum menggunakan media berbasis komputer. Dengan menggunakan permainan Make a Match berbasis komputer, guru dapat menghemat waktu untuk menjelaskan dengan rinci materi tertentu yang perlu dijelaskan kembali secara struktural. Oleh karena itu, media ini dianggap sesuai untuk diterapkan dalam kegiatan pengayaan mengingat adanya keterbatasan waktu dalam pembelajaran pada saat di kelas.

Kelebihan yang terdapat dari permainan Make a Match berbasis komputer dalam media pengayaan ini adalah game yang menggunakan desain visual yang inovatif dilengkapi dengan feedback secara otomatis dalam bentuk penskoran dan pembahasan materi untuk setiap pengerjaan butir latihan soal yang telah dikerjakan. Selain itu, media didesain untuk menawarkan desain visual yang menyenangkan bagi peserta didik yang tujuan sebenarnya adalah menghadirkan pengalaman belajar.

Dengan permainan Make a Match berbasis komputer ini siswa merasa tidak terbebani dengan pengulangan beberapa materi di bagian tertentu karena disamping peserta didik kembali dihadapkan pada materi yang telah diperoleh, disisi lain peserta didik juga dapat bermain dengan santai dan menyenangkan. Asich (2017) mengatakan bahwa permainan kartu Make a Match dapat 
memotivasi peserta didik, memberikan bantuan belajar sebesar 96\%, meningkatkan semangat dalam belajar, serta mampu menarik perhatian siswa sebesar 96\%. Hasil penelitian Arno, Atmadja, \& Maryati (2017) dan Febriana (2011) menyimpulkan bahwa model pembelajaran kooperatif teknik Make a Match (mencari pasangan) dapat meningkatkan aktivitas siswa. Menurut Mardati \& Wangid (2015), permainan kartu gambar dengan teknik Make a Match ini efektif dan praktis digunakan dalam pembelajaran. Media pengembangan permainan Make a Match berbasis komputer ini dapat dikatakan lebih unggul dibandingkan dengan media konvensional karena, media pembelajaran berbasis komputer mempermudah proses pembelajaran agar lebih berjalan secara efektif dan efisien.

\section{METODE PENELITIAN}

Jenis penelitian yang digunakan pada penelitian ini ialah pengembangan atau disebut Research and Development (R\&D). Metode yang diterapkan yakni analysis, design, development, implementation, dan evaluation atau ADDIE yang dikembangkan oleh Pribadi (2011). Subjek uji coba penelitian ini mencakup beberapa para ahli yang terdiri ahli materi, ahli media yang telah profesional pada pengembangan media berbasis komputer (dosen Kurikulum dan Teknologi Pendidikan), dan ahli bahasa yang berkompeten dalam tatanan bahasa (dosen Bahasa Indonesia).

Teknik pengumpulan data menggunakan angket terbuka dan tertutup. Hasil dari angket tersebut kemudian dianalisis menggunakan lembar telaah berupa masukan dan koreksi. Hal ini dimaksudkan agar kekurangan dalam produk yang berhubungan dengan kualitas dan format produk serta konsep produk yang dikembangkan dapat diperbaiki. Sedangkan lembar validasi berupa data kuantitatif yang disajikan dalam persentase dengan skala likert 1-5.

\section{HASIL PENELITIAN DAN PEMBAHASAN \\ Pengembangan Permainan Make a Match Berbasis Komputer Sebagai Media Pengayaan}

Berdasarkan tahapan dalam pengembangan media, peneliti mengadakan analisis kebutuhan yang diperlukan untuk mengembangkan sebuah media. Pada tahap ini, analisis dilakukan terhadap materi yang akan dilaksanakan dalam kegiatan pengayaan. Selanjutnya peneliti menganalisis rumusan tujuan pembelajaran dengan melakukan analisis kompetensi dasar, kompetensi inti, serta indikator yang dilaksanakan untuk pengembangan permainan Make a Match berbasis komputer. Hasil perumusan tujuan pembelajaran digunakan untuk dasar penyusunan desain perangkat. Penerapan Make a Match banyak digunakan oleh peneliti sebelumnya untuk meningkatkan kemampuan membaca komprehensif (Irwanto \& Nurpahmi, 2017). Dari hasil analisis di atas maka media yang akan dikembangkan adalah permainan Make a Match berbasis komputer sebagai media pengayaan. Hal tersebut mampu melibatkan partisipasi antar siswa yang sudah tuntas yang bertujuan menumbuhkan motivasi dan keaktifan siswa dalam kegiatan pengayaan, sebagaimana pada penelitian sebelumnya (Juliani, Mustadi, \& Lisnawati, 2020). Karakteristik siswa yang dapat dijadikan subjek uji coba berdasarkan kemampuan dan pengalaman belajar yaitu siswa kelas XI Akuntansi yang sudah menempuh materi persediaan. 
Pada tahap design, hasil analisis kemudian dibuat desain awal permainan Make a Match berbasis komputer untuk program pengayaan di kelas. Dengan menggunakan media yang inovatif dan variatif, pembelajaran dapat berlangsung menyenangkan dan menarik. Konsep awal menentukan materi di dalam permainan ini yaitu menyesuaikannya dengan silabus yang berdasarkan Kurikulum 2013 revisi 2018 sesuai dengan Peraturan Menteri Pendidikan dan Kebudayaan No. 37 Tahun 2018 pada materi persediaan. Selanjutnya, membuat dan memasukkan isi dan pertanyaan yang sesuai dengan materi. Kemudian merancang desain permainan Make a Match menggunakan aplikasi Construct 3 dan Photoshop. Terdapat beberapa menu dalam permainan ini diantaranya yaitu tampilan awal atau icon permainan Make a Match (home), profil, materi, petunjuk penggunaan, tutorial permainan, dan masuk game.
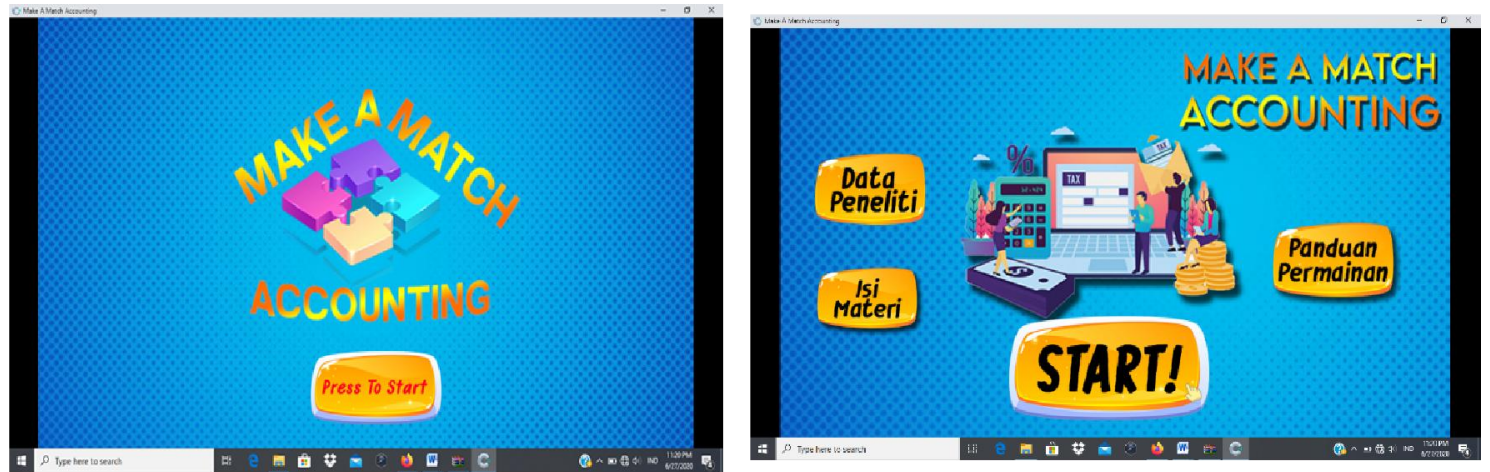

Gambar 1.

Tampilan Awal Make a Match

Berikutnya yakni tahap development dimana produk yang dikembangkan berupa rancangan media (storyboard) yang telah didesain, sehingga dapat memperoleh produk desain awal media pengayaan Make a Match berbasis komputer pada materi persediaan. Gambar 1 merupakan tampilan awal pada permainan Make a Match. Peserta akan dihadapkan pada pemilihan beberapa menu seperti data peneliti, isi materi dan panduan permainan serta tombol start. Setelah tombol start ditekan, maka peserta akan masuk dalam permainan utama yang tergambar pada Gambar 2 dan Gambar 3.

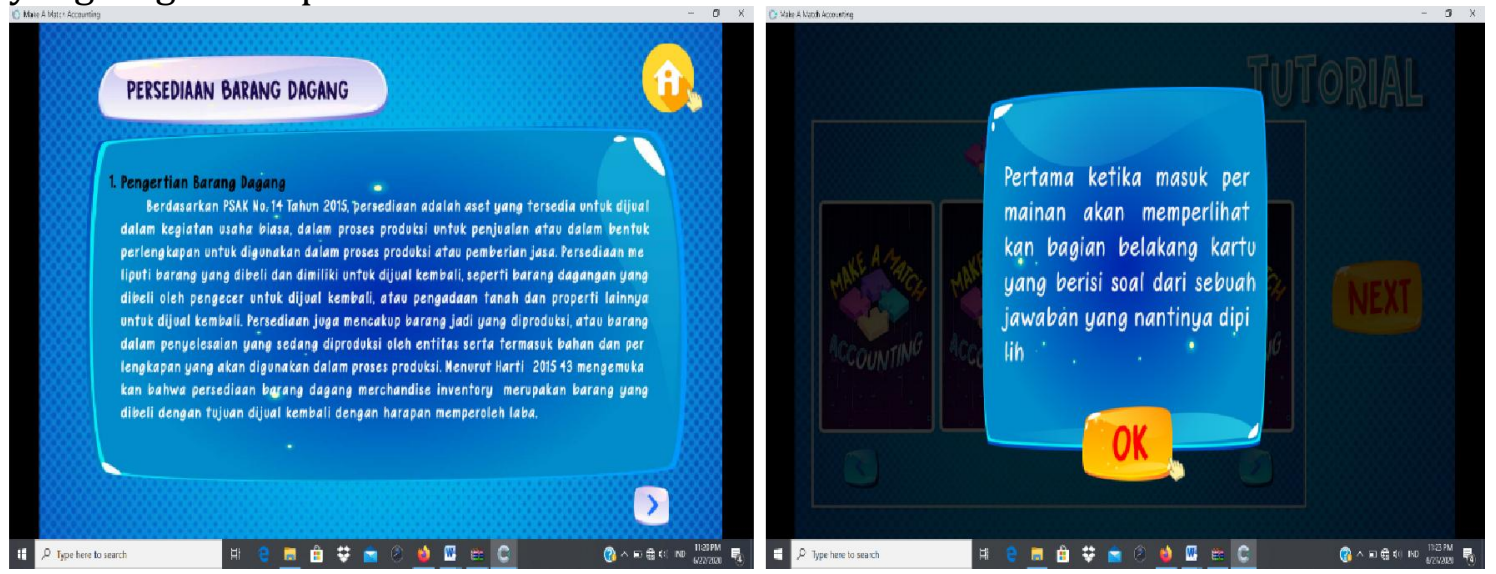

Gambar 2.

Persiapan Make a Match

Jurnal Pendidikan IImu Sosial, Vol 30, No.2, Desember 2020,

p-ISSN: 1412-3835; e-ISSN: 2541-4569 
Selanjutnya, media yang ada ditelaah oleh para ahli yang sesuai di bidangnya. Penilaian tersebut nantinya akan menjadi dasar yang digunakan untuk revisi dan penyempurnaan produk lebih lanjut. Peneliti menerima komentar beserta saran yang diperoleh dari ketiga para ahli yang menilai kelayakan dalam pemainan Make a Match berbasis komputer sebagai media pengayaan materi persediaan. Ahli materi 1 (dosen Pendidikan Akuntansi Universitas Negeri Surabaya/UNESA) dan ahli materi 2 (guru mata pelajaran) memberikan saran untuk materi yang disajikan harus memenuhi kriteria HOTS (Higher Order Thinking Skills). Ahli bahasa (dosen Bahasa Indonesia UNESA) memberikan saran pada penulisan kalimat, huruf miring pada istilah asing, kata baku, konjugasi (kata penghubung), dan funguatus (tanda baca). Ahli media (dosen Kurikulum dan Teknologi Pendidikan UNESA) memberika saran untuk media berupa pemilihan warna dalam permainan dan menambahakan fitur jeda (pause) dalam pengerjaan soal.

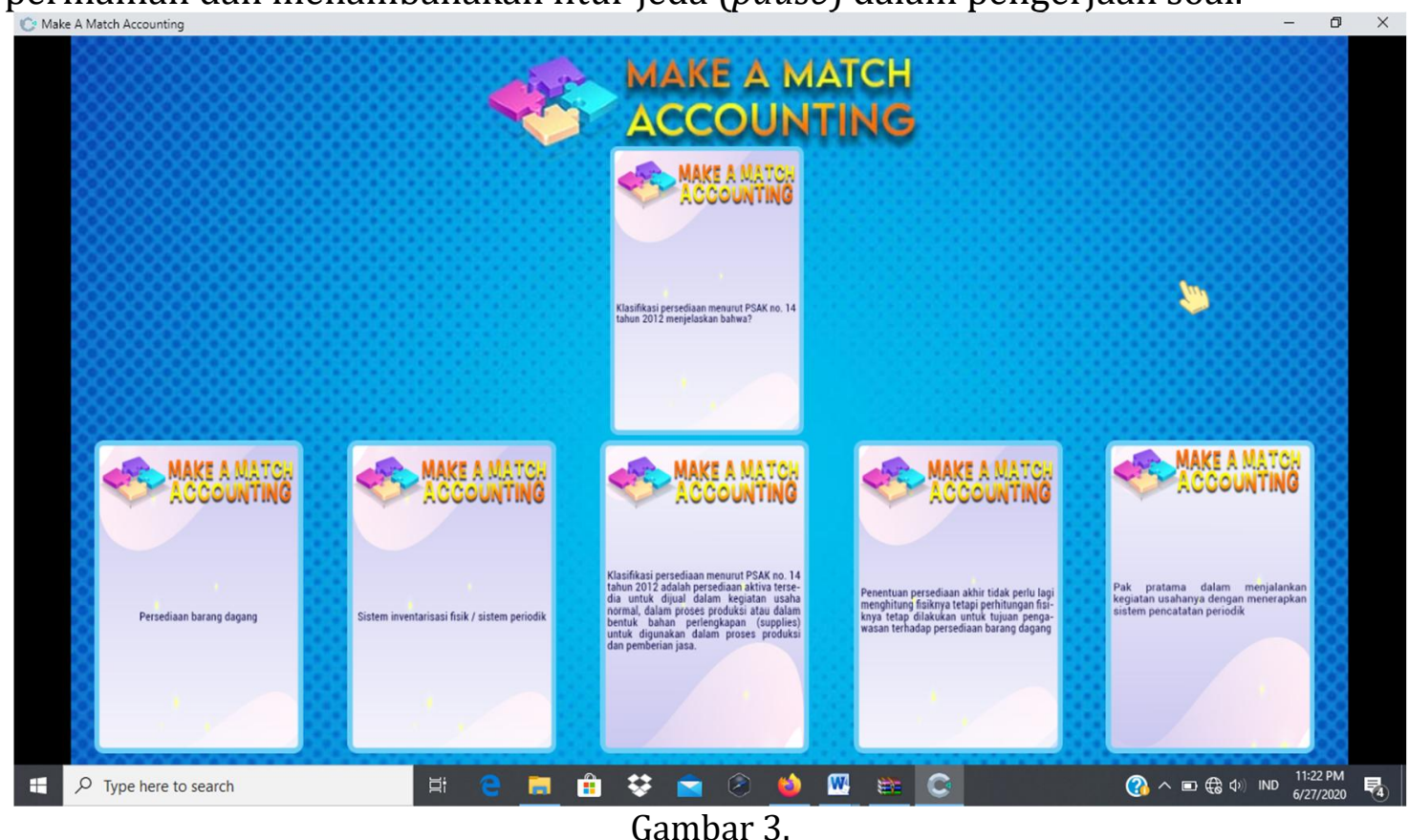

Permainan Make a Match

Setelah menerima hasil telaah dari para ahli, maka dilakukan revisi produk sesuai dengan saran hingga media permainan Make a Match berbasis komputer ini dinilai layak oleh para ahli. Hasil revisi dianalisis dan divalidasi. Selanjutnya menganalisis hasil validasi untuk mengetahui persentase kelayakan permainan Make a Match berbasis komputer yang dikembangkan.

Penelitian ini telah selaras dengan penelitian yang dilakukan oleh Asich (2017)dimana penelitian yang dilakukan adalah pengembangan permainan kartu Make a Match dengan mengaplikasikan model pengembangan yang selaras yaitu ADDIE yang mengadaptasi dari Pribadi (2011) yang terdiri dari tahap analysis, design, development, implementation, dan evaluation. Penelitian yang dilakukan Asich belum menggunakan berbasis teknologi komputer dalam mengembangkan permainan Make a Match. Sementara itu, penelitian yang dilakukan oleh Asrini \& Susanti (2017) mengembangkan permainan Merchandise Inventory berbasis 
komputer dengan menggunakan metode pengembangan yang selaras yaitu pengembangan ADDIE yang mengadaptasi dari Pribadi (2011).

\section{Validasi dan Kelayakan Permainan Make a Match Berbasis Komputer sebagai Media Pengayaan}

Kelayakan permainan Make a Match berbasis komputer sebagai media pengayaan materi persediaan dihitung dari hasil validasi ahli materi, bahasa, dan media. Lembar validasi dari para ahli dinilai sesuai dengan skala likert kemudian hasil penilaian akan didefinisikan dalam bentuk presentase dimana media tersebut dapat disebut layak jika rata-rata validasi $\geq 61 \%$.

Terdapat dua validator yang melakukan validasi terhadap materi permainan Make a Match berbasis komputer yakni validator 1 dari dosen Pendidikan Akuntansi UNESA dan validator 2 dari guru Mata Pelajaran Akuntansi Keuangan Kelas XI SMK N 10 Surabaya. Hasil yang diperoleh dari aspek kualitas isi dan tujuan sebesar 90,66\% dan kualitas instruksional sebesar 90\%. Dengan demikian, diperoleh rata-rata keseluruhan aspek sebesar 90,71\% dimana dapat dikatakan sangat layak. Menurut Pratiwi, Hidayah, \& Martiana (2017), penggunaan soal-soal yang beradaptasi pada HOTS dapat menuntut siswa mempunyai kemampuan berpikir tingkat tinggi. Validasi bahasa untuk permainan Make a Match berbasis komputer ini dilakukan oleh Dosen Bahasa Indonesia UNESA. Hasil validasi dari ahli bahasa menunjukkan bahwa rincian aspek kelayakan kebahasaan mendapatkan hasil persentase $81,4 \%$ sehingga media dapat dikatakan sangat layak. Selanjutnya validasi media untuk permainan Make a Match berbasis komputer dilakukan oleh Dosen Kurikulum dan Teknologi Pendidikan UNESA. Hasil validasi dari ahli media menunjukkan bahwa rincian aspek perangkat lunak dan komunikasi visual memperoleh persentase $86,7 \%$ yang termasuk dalam intrerpretasi kategori sangat layak. Oleh karena itu, materi persediaan yang dikembangkan dengan permainan Make a Match berbasis komputer ini tergolong pada kriteria sangat layak untuk digunakan sebagai media pengayaan bagi siswa yang telah mencukupi KKM.

Seluruh hasil validasi yang telah dinilai kelayakannya oleh para validator memperoleh rata-rata validasi dapat diketahui pada Tabel 1 berikut ini:

Tabel 1.

Rekapitulasi Hasil Validasi Para Ahli

\begin{tabular}{llcc}
\hline No & Validasi & Presentase (\%) & Kriteria Kelayakan \\
\hline 1. & Ahli Materi & $90,71 \%$ & Sangat Layak \\
2. & Ahli Bahasa & $81,4 \%$ & Sangat Layak \\
3. & Ahli Media & $86,7 \%$ & Sangat Layak \\
Rata-rata & $86,27 \%$ & Sangat Layak \\
\hline
\end{tabular}

Sumber : Data diolah oleh peneliti (2020)

Hasil rekapitulasi validasi dari para ahli menunjukkan bahwa pengembangan permainan Make a Match berbasis komputer memperoleh rata-rata penilaian kelayakan sebesar 86,27\% yang artinya media ini dapat dikatakan sangat layak. Dengan demikian, hasil penelitian ini telah sesuai dengan penelitian yang dilakukan oleh Asich (2017) yang menyatakan bahwa permainan kartu Make a Match sangat layak digunakan untuk mendukung program pengayaan. Hal ini 
dikarenakan media yang dikembangkan dapat memberikan bantuan belajar, memotivasi peserta didik, membantu siswa belajar secara mandiri, meningkatkan semangat dalam belajar, dan mampu menarik perhatian siswa. Adapun penelitian lain yang relevan yaitu penelitian dari Mardati \& Wangid (2015) yang membuktikan bahwa permainan kartu gambar dengan teknik Make a Match telah sangat layak untuk digunakan guna mendukung kegiatan pembelajaran yang efektif dan praktis. Demikian juga pada penelitian dari Dianayanti \& Sumantri (2020) dan Wibowo \& Marzuki (2015) yang mengulas tentang peningkatan motivasi, rasa percaya diri siswa, dan keaktifan siswa dalam pembelajaran melalui Make a Match.

\section{KESIMPULAN}

Pengembangan permainan Make a Match berbasis komputer sebagai media pengayaan dinyatakan layak untuk diterapkan dalam program pengayaan bagi peserta didik yang telah mencukupi KKM. Kelayakan ini diperoleh berdasarkan hasil validasi oleh ahli materi, ahli bahasa, dan ahli media dengan menggunakan data kuantitatif yang menghasilkan penilaian berbentuk persentase dengan skala likert. Media ini perlu diuji implementasi pada peserta didik yang telah mencapai KKM untuk mengukur efektivitas media ketika diimplementasikan. Media yang dibangun masih memungkinkan untuk dilakukan revisi apabila hasil implementasi menunjukkan efektivitas yang rendah.

\section{DAFTAR PUSTAKA}

Afanty, S., Siswandari, \& Jaryanto. 2016. Keefektifan Penerapan Model Pembelajaran Make A Match dan Cooperative Script Terhadap Hasil Belajar Kognitif Siswa Pada Pembelajaran Akuntansi SMK Surakarta. Jurnal "Tata Arta” UNS, 5 (1), 121-133.

Aghni, R. I. 2018. Fungsi dan Jenis Media Pembelajaran Dalam Pembelajaran Akuntansi. Jurnal Pendidikan Akuntansi Indonesia, $16 \quad$ (1), 98-107. https://doi.org/10.21831/jpai.v16i1.20173.

Andriyani, R. 2015. Penerapan Model Pembelajaran Kooperatif Teknik Make A Match untuk Meningkatkan Motivasi dan Prestasi Belajar Akuntansi Siswa Kelas X AK SMK Muhammadiyah 2 Yogyakarta Tahun Ajaran 2014/2015. Skripsi. Pendidikan Akuntansi, Fakultas Ekonomi, Universitas Negeri Yogyakarta.

Arno, Atmadja, N. B., \& Maryati, T. 2017. Penerapan Model Pembelajaran Teknik Make A Match (Kartu Berpasangan) untuk Meningkatkan Aktivitas dan Hasil Belajar Siswa Pada Mata Pelajaran IPS Kelas VIII G Semester Genap di SMP Negeri 3 Singaraja Buleleng Bali Tahun Ajaran 2014/2015. Widya Winayata: Jurnal Pendidikan Sejarah, 5 (1). http://dx.doi.org/10.23887/jjps.v5i1.5382.

Asich, I. 2017. Pengembangan Permainan Kartu Make A Match Sebagai Media Pengayaan Pada Materi Jurnal Penyesuaian Perusahaan Dagang. Jurnal Pendidikan Akuntansi, 01 (01), 1-7. 
Asrini, Y. P., \& Susanti. 2017. Pengembangan Media Pengayaan Merchandise Inventory Game Pada Mata Pelajaran Akuntansi Perusahaan Dagang Siswa Kelas XI Akuntansi SMK Negeri di Surabaya. Jurnal Pendidikan Akuntansi (JPAK), 5 (2), 1-7.

Darmawan, D. 2015. Teknologi Pembelajaran. Bandung: PT Remaja Rosdakarya.

Dianayanti, N, L, P., \& Sumantri, M. 2020. Model Pembelajaran Make A Match Berbantuan Media Audiovisual Terhadap Kompetensi Pengetahuan IPS. Mimbar PGSD Undiksha, 8 (2), 170-180.

Dirman, \& Juarsih, C. 2014. Penilaian dan Evaluasi Dalam Rangka Implementasi Standar Proses Pendidikan Siswa. Jakarta: PT Rineka Cipta.

Febriana, A. 2011. Penerapan Model Pembelajaran Kooperatif Tipe Make A Match untuk Meningkatkan Kualitas Pembelajaran IPS Siswa Kelas V SDN Kalibanteng Kidul 01 Kota Semarang. Jurnal Kependidikan Dasar, 1 (2), 151-161.

Hamdani. 2011. Strategi Belajar Mengajar. Bandung: Pustaka Setia.

Irwanto, \& Nurpahmi, S. 2017. Using Make-A Match to Improve The Students' Reading Comprehension at MTS Guppi Samata Gowa. ETERNAL (English, Teaching, Learning $\begin{array}{llll}\text { and Research } 3 \text { Journal), } & \text { 159-169. }\end{array}$ https://doi.org/10.24252/eternal.v32.2017.a5.

Juliani, A., Mustadi, A., \& Lisnawati, I. 2020. "Make A Match Model" for Improving The Understanding of Concepts and Student Learning Results. Indonesian Journal on Learning and Advanced Education (IJOLAE), 3 (1), 48-56. https://doi.org/10.23917/ijolae.v3i1.10269.

Lie, A. 2010. Cooperative Learning: Mempraktikkan Cooperative Learning di Ruang-ruang Kelas. Jakarta: Grasindo.

Mardati, A., \& Wangid, M. N. 2015. Pengembangan Media Permainan Kartu Gambar Dengan Teknik Make A Match untuk Kelas I SD. Jurnal Prima Edukasia, 3 (2), 120132.

Mukhtar, \& Rusmini. 2005. Pengajaran Remedial: Teori dan Penerapannya dalam Pembelajaran. Jakarta: PT Nimas Multima.

Mulyasa. 2014. Pengembangan dan Implementasi Kurikulum 2013. Bandung: PT Remaja Rosdakarya.

Pratiwi, P. H., Hidayah, N., \& Martiana, A. 2017. Pengembangan Modul Mata Kuliah Penilaian Pembelajaran Sosiologi Berorientasi HOTS. Jurnal Cakrawala Pendidikan, 36 (2), 201-209.

Pribadi, B. A. 2011. Model Desain Sistem Pembelajaran. Jakarta: PT Dian Rakyat. 
Setyosari, P. 2014. Menciptakan Pembelajaran yang Efektif dan Berkualitas. Jurnal Inovasi $\begin{array}{lllll}\text { Dan Teknologi } & \text { Pembelajaran, } & 1 & \text { (1), }\end{array}$ https://doi.org/10.17977/um031v1i12014p020.

Wibowo, K. P., \& Marzuki. 2015. Penerapan Model Make A Match Berbantuan Media untuk Meningkatan Motivasi dan Hasil Belajar IPS. Harmoni Sosial: Jurnal Pendidikan IPS, 2 (2), 158-169. https://doi.org/10.21831/hsjpi.v2i2.7667.

Wulandari, L. T. 2012. Penerapan Model Pembelajaran Kooperatif Metode Make A Match untuk Meningkatkan Hasil Belajar Materi Laporan Keuangan Kelas X Akuntansi SMK Negeri Mojoagung. Jurnal Pendidikan Akuntansi (JPAK), 01 (01), 1-7. 